\title{
Charles W. Lightollers
}

Author(s): B. St. J. B. Joule

Source: The Musical Times and Singing Class Circular, Vol. 31, No. 572 (Oct. 1, 1890), p. 617

Published by: Musical Times Publications Ltd.

Stable URL: http://www.jstor.org/stable/3361182

Accessed: 11-05-2016 13:24 UTC

Your use of the JSTOR archive indicates your acceptance of the Terms \& Conditions of Use, available at

http://about.jstor.org/terms

JSTOR is a not-for-profit service that helps scholars, researchers, and students discover, use, and build upon a wide range of content in a trusted digital archive. We use information technology and tools to increase productivity and facilitate new forms of scholarship. For more information about JSTOR, please contact support@jstor.org.

Musical Times Publications Ltd. is collaborating with JSTOR to digitize, preserve and extend access to The Musical Times and Singing Class Circular 
and choirs shows that the general wish is to have the service conducted in a less discordant manner than formerly.

I cannot close without protesting very strongly against the tone of Bishop Mitchinson's letter, everybody in the church (except the clergyman!) being apostrophised as "dogs." Such language is not likely to add weight to the cause he advocates.-Yours, \&c.,

Cholrmaster.

\section{NEW SIGN FOR THE DOUBLE FLAT}

TO THE EDITOR OF "THE MUSICAL TIMES."

SIR,-Regarding the ingenious new signs for the double flat Mr. Ross has invented, I should think the second one would be decidedly the best, as occupying the least space. It would, where applied to a note in the middle of a chord, be less likely to refer to any note but its own; and also, being more like the sign already in use, it would be familiar at once, and could be read even at first without any hesitation.

As it is really made up from our present sign, could not the sign we also now use for the contradiction be combined to form the required new sign? Perhaps the following may be of use, or a more acceptable way may be found of expressing the same idea.

I am, Sir, your obedient servant,

FELIX.

TO THE EDITOR OF “THE MUSICAL TIMES."

SIR, - I was very much interested in the invention of the single sign for the double flat by Mr. Ross. The first sign given of the two seems the clearer, and one which could be easily contradicted as follows :

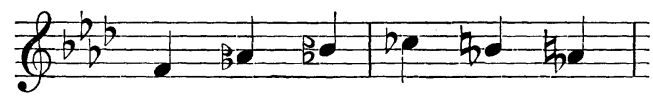

No doubt such signs would make the spacing of music much neater.-Yours faithfully,

7, Upper Surrey Street,

All Saints' Green, Norwich.

REV. F. T. HAVERGAL, D.D.

TO THE EDITOR OF “THE MUSICAL TIMES."

SiR,-As future generations will, doubtless, consult your valuable and interesting journal on the "History of our own times" and the people who lived in them, I venture to set the writer of the notice of the above Prebendary, in this month's issue, right on two minor points.

(r) His father, W. H. (not brother, H. E.), was Honorary Canon of Worcester.

(2) Frances Ridley was his younger (not elder) sister; she was, in fact, the youngest of the family.

Although these are really small matters, I think you will agree with me that it is best to be as accurate as we can in this world of error.

This must be my apology for troubling you.

$$
\text { I am, yours truly, }
$$

Arthur Havergal.

September $\mathbf{1}_{5}, \mathrm{r} 890$.

\section{BATES AND HARROP.}

TO THE EDITOR OF " THE MUSICAL TIMES."

Sir,-C Can any of your readers give me the following information: The age, place of death, and burial of Joah Bates, well known in the musical world from 1776 to 1793 ? He died June 8, 1799. Also date and place of death, age and place of burial of his wife, whose name before marriage the Dictionary of Music and Musicians, edited by George Grove, I879, states was Sarah Harrop? If she was born before I750, I think it would be Mary.-Yours truly,

\section{PIANOFORTE FINGERING, ENGLISH AND FOREIGN}

TO THE EDITOR OF "THE MUSICAL TIMES."

Sir,-Allow me to thank you for so neatly tripping up one of the legs upon which Mr. Cummings seems to expect that foreign fingering will march to victory. You say that the third finger is commonly known as the ring finger-precisely so; and so says every lady and gentleman in the land. But Mr. Cummings contends that the antiquated directions to which he refers, say that the fourth is the ring finger. As to the other leg, the physiological dealing with the hand, I beg to say that all physiologists do not speak of the thumb as a finger, so that that prop also is not to be relied on. As to the "Five Finger Exercises," I believe Henri Herz was the originator of them; he wanted a compact and taking title, and pitched upon that, in which he has been followed by others; but his choice of a title does not make the thumb a finger-and it must be remembered that he used the cross for the thumb, and not a figure. My argument, which I commend to your consideration, in brief is this: The English system of fingering coincides with everything properly related thereto, the numbers in general use for the fingers, and those employed in the instruction for various instruments, and promotes in this way the uniformity of our musical system ; and is therefore the best system that can be devised, and ought in any way to be retained. The foreign system, on the other hand, coincides with nothing, and if adopted would lead to inextricable confusion in our musical system; and, therefore, should by no means be accepted. If we are to have but one system (though some people seem to think it does not matter about having two), let that be the best; and let us do our endeavour to bring our foreign brethren to the true track.-Yours truly,

St. Martin's East, Leicester,

C. Oldershaw. September I8, I89o

\section{CHARLES W. LIGHTOLLERS}

TO THE EDITOR OF "THE MUSICAL TIMES."

SiR,-The only notice I have seen of the late Charles William Lightollers, who died at Southport, on August 2I, was in the Manchester Courier, in a paragraph which detailed, at considerable length, his duties as chief clerk at the Manchester Diocesan Registry, from its formation until his retirement a few months ago through failing health, but restricted to little over two lines any allusion to his musical ability, that little being quite incorrect. That $\mathrm{Mr}$. Lightollers possessed very considerable musical talent is evidenced by his compositions, a list of which I subjoin :A complete Morning, Evening, and Communion Service; in use at the Cathedral and at St. Peter's Church, Manchester, with arrangements for the Offertory Sentences. Three anthems, many chants and hymn-tunes, also a partsong which has been favourably received at the concerts of the Manchester Vocal Society, of which he was a member many years. He also composed two sketches for the organ. Only the part-song, two chants, and three hymn-tunes have been published.

At one time he was Organist and Choirmaster at the Church of St. John the Baptist, Hulme, and subsequently became a member of the choir at St. Peter's Church, but he never played the organ there.

Mr. C. W. Lightollers, who some time ago restored the final " $\mathrm{s}$ " in his name, belonged to a musical family. Richard, his eldest brother, was well known in Chorley. George Henry, J.P., and Major in the L.R.V., displayed so much musical talent that Dr. Wesley, from whom he took lessons, was anxious that he should adopt music as a profession. His brother Robert for some time played the organ at St. Alban's, Cheetham. The late Mr. Lightollers was an indefatigable worker. After resigning his position in the choir of St. Peter's, when he found his voice deteriorating, he spontaneously arranged and made an exhaustive catalogue of the musical works in the library at that church-no slight task.

Rothesay.
B. ST. J. B. JOULE. 